\title{
EL NUEVO PROCESO RELATIVO A LA SUSTRACCIÓN INTERNACIONAL DE MENORES*
}

\author{
Juan Ramón LIÉBANA ORTIZ \\ DOCTOR EN DERECHO \\ PROFESOR DE DERECHO PROCESAL \\ UNIVERSIDAD INTERNACIONAL DE LA RIOJA
}

\begin{abstract}
SUMARIO: I. Introducción. I.I. La sustracción internacional de menores. I.2. Sustracción internacional de menores, Derechos Humanos y proceso civil. I.3. La nueva regulación procesal de la sustracción internacional de menores. II. Ámbito de aplicación del proceso relativo a la restitución o retorno de menores en los supuestos de sustracción internacional. II.I. Convenio sobre los aspectos civiles de la sustracción internacional de menores, hecho en La Haya el 25 de octubre de i980. II.2. Convenio entre el Reino de España y el Reino de Marruecos sobre asistencia judicial, reconocimiento y ejecución de resoluciones judiciales en materia de derecho de custodia y derecho de visita y devolución de menores, hecho en Madrid el 30 de mayo de I997. II.3. Convenio del Consejo de Europa sobre reconocimiento y ejecución de decisiones en materia de custodia de menores y restablecimiento de dicha custodia, hecho en Luxemburgo el 20 de mayo de I980. II.4. Reglamento (CE) núm. 2201/2003, del Consejo, de 27 de noviembre de 2003, relativo a la competencia, el reconocimiento y la ejecución de resoluciones judiciales en materia matrimonial y de responsabilidad parental. II.5. La cooperación jurídica internacional y el procedimiento de exequatur. III. Competencia, legitimación y postulación. III.r. Órgano jurisdiccional competente. III.2. Legitimación y postulación. III.3. La intervención del Ministerio Fiscal. IV. Procedimiento para la restitución o retorno de menores en los supuestos de sustracción internacional.
\end{abstract}

RESUMEN: El presente trabajo analiza el nuevo proceso relativo a la restitución de menores en supuestos de sustracción internacional tal y como se regula en la Ley de Enjuiciamiento Civil tras su reciente incorporación por la Ley de Jurisdicción Voluntaria, estudiando tanto su objeto, como los sujetos intervinientes, así como su tramitación procedimental.

PalabraS ClAVE: Sustracción internacional de menores, interés superior del menor, proceso civil especial, jurisdicción voluntaria.

ABSTRACT: This paper analyses the brand new process to bring about the children return in the event of an international abduction as stated in the Spanish Rules of Civil Litigation after its recent incorporation by the Voluntary Jurisdiction Law, focusing on its scope, the legal subjects intervening in it, as well as its proceeding.

KEYwORDS: International children abduction, best interests of the children, special civil process, voluntary jurisdiction.

* El presente trabajo se ha realizado en el marco del Proyecto de Investigacion UNIR Research Justicia, Derecho y Globalización. 


\section{Introducción}

\section{I.I. La sustracción internacional de menores}

La sociedad actual propicia las relaciones personales y laborales entre personas de distintos países, culturas y religiones; una nueva realidad social que ha llevado aparejado un correlativo aumento de los matrimonios y parejas de análoga relación de afectividad en que cada uno de los miembros es nacional de un país diferente. Paralelamente, la sociedad en la que vivimos se caracteriza por un importante aumento de las crisis matrimoniales y de las parejas de hecho, con los consiguientes procesos judiciales de separación, divorcio y de medidas definitivas sobre los hijos.

La sustracción internacional de menores tiene lugar cuando un menor es trasladado ilícitamente por uno de los progenitores a un país distinto de donde residen habitualmente, violando el derecho de custodia atribuido a una persona o a una institución, y en aquellos casos en que uno de los progenitores se traslada con el menor para residir en otro país, tomando tal decisión de forma unilateral y vulnerando el derecho a decidir sobre el lugar de residencia del menor.

De este modo, no es difícil concluir que la mayoría de supuestos de sustracción internacional de menores se dan al producirse la crisis matrimonial o de pareja en la que existe un elemento extranjero: cada uno de los miembros de la unidad familiar tenderá a buscar la protección de sus intereses, y la eventual custodia y régimen de visita de sus hijos menores de edad, conforme a su ley nacional y bajo la tutela de las autoridades de su país.

La sustracción internacional de menores implica precisamente la utilización por los particulares de vías de hecho para crear vínculos artificiales de competencia judicial con vistas a obtener su custodia o un régimen de visitas más ventajosó. Por ello, el problema jurídico que plantean las sustracciones internacionales de menores deriva de la posibilidad que tienen los particulares de establecer vínculos más o menos artificiales de competencia judicial internacional lo que, unido a las diferencias en los Derechos internos, les hace pensar en la posibilidad de obtener una decisión favorable a sus intereses que, además, legitimaría su acción; máxime cuando la actuación de la autoridad bajo cuya tutela se sitúa no tiene por qué suponer ningún tipo de irregularidad. Además, la búsqueda de unos Tribunales ad hoc, favorecedores de las posiciones de los secuestradores, es especialmente dramática en supuestos en los que los progenitores son no sólo de distintas nacionalidades sino pertenecientes a distintas culturas o civilizaciones.

Debe señalarse que, en todo caso, el traslado o la retención en otro país de un menor por uno de sus progenitores (ya lo haga el progenitor no custodio que disfruta de un régimen de visitas, ya el progenitor que tiene la custodia en exclusiva o el progenitor que comparte custodia) sin el consentimiento de otro constituye un acto de violencia que afecta de forma especial al menor, que es utilizado como objeto de presión entre sus padres, enfrentándolo a cambios bruscos de tipo social y familiar, privándole del afecto y de la

${ }^{I}$ Vid., en este sentido, el Informe explicativo del Convenio núm. XVIII de la conferencia de La Haya sobre los aspectos civiles de la sustracción de menores, de 25 de octubre de 1980, pág. 3, hecho en Madrid en abril de I98I por la Prof. ${ }^{a}$ Elisa PÉREZ VERA, en el enlace web http://www.hcch.net/upload/expl28s.pdf 
relación de la familia con quien convivía; lo que en muchas ocasiones genera graves repercusiones psicopatológicas tanto en el progenitor privado de las relaciones con su hijo como del propio menor objeto del traslado o retención ilícitas.

Resulta evidente pues que en los supuestos en los que un menor con residencia habitual en España sea trasladado a o retenido en otro país por uno de los progenitores sin el consentimiento del otro supone no ya sólo la vulneración del art. I6o CC que regula el derecho de los progenitores a relacionarse con sus hijos menores aunque no tengan atribuida la patria potestad, sino también el derecho a la protección de la familia y la infancia reconocido en el art. 39 CE como uno de los principios rectores de la política social, económica y jurídica de nuestro ordenamiento.

\section{I.I. Sustracción internacional de menores, Derechos Humanos y proceso civil}

La vinculación de la sustracción internacional de menores con los derechos fundamentales ha sido jurisprudencialmente desarrollada por el Tribunal Europeo de Derechos Humanos (CEDH en adelante) en su interpretación del derecho al respeto a la vida privada y familiar contenido en el art. 8 del Convenio Europeo de Derechos Humanos de 4 de noviembre de I950.

En efecto, el art. $8 \mathrm{CEDH}$ tiene por objeto la protección del individuo contra injerencias arbitrarias de los poderes públicos, generando obligaciones positivas que son inherentes al respeto efectivo de la vida familiar. En el caso de los secuestros internacionales de menores, ello «implica el derecho de un progenitor a medidas apropiadas para que se pueda reunir con su hijo y la obligación por parte de las autoridades nacionales de tomar dichas medidas»' Convención de Derechos del Niño y el Convenio de La Haya de I98033.

El propio Tribunal Europeo de Derecho Humanos ha puesto de relieve en reiterada jurisprudencia que el respeto a los derechos fundamentales tanto del menor como del progenitor ilegalmente privado de su derecho a relacionarse con su hijo o a tenerlo en su compañía por haberse visto envuelto el menor en una sustracción internacional por parte de su otro progenitor tiene una necesaria vinculación con el proceso civil. En efecto, en los procesos relativos a la restitución o retorno de menores en los supuestos de sustracción internacional deben ser absolutamente prioritarios el interés superior del menor, en su vertiente sustantiva, y la celeridad, en su dimensión procesal.

En efecto, desde el punto de vista del Derecho sustantivo, el concepto del superior interés del menor debe ser primordial en los procesos de esta índole, entendiéndose por tal el mantenimiento de los lazos familiares con ambos progenitores, puesto que el Convenio

\footnotetext{
${ }^{2}$ Cfr. SSTEDH de 22 de junio de I989, Eriksson contra Suecia (TEDH I989\I2); de 25 de febrero de I992, Margareta y Roger Anderson contra Suecia (TEDH I992\4); de 2 de noviembre de I992, Olsson contra Suecia; de 23 de septiembre de I994, Hokkanen contra Finlandia (TEDH I994\35); de 25 de enero de 2000, IgnaccoloZenide contra Rumanía (TEDH 2000|I4); de 22 de septiembre de 2009, Stochlak contra Polonia (TEDH 2009\96); de 24 de mayo de 20II, Saleck Bardi contra España (TEDH 20II $\ 5$ ); de 27 de octubre de 20II, Bergmann contra República Checa (JUR 20II $\backslash 363672$ ).
}

${ }^{3}$ Así, STEDH de 22 de diciembre de 2009, Tapia Gasca y D. contra España (TEDH 2009\I45). 
Europeo de Derecho Humanos establece obligaciones positivas inherentes al respeto efectivo de la vida familiar4.

Así, debe partirse de que el derecho a relacionarse con los hijos, y el derecho de visitas en caso de no convivir, se integra en el derecho a la vida familiar reconocido en el art $8 \mathrm{CEDH}$, puesto que el disfrute mutuo de la compañía de padres e hijos constituye un elemento fundamental de la vida familiars.

Por lo que respecta a la regulación procesal el principio de celeridad es fundamental: la adecuación de una medida debe ser juzgada por la rapidez de su implementación, en tanto el paso del tiempo puede tener consecuencias irreparables en la relación entre los niños y el padre que no vive con ellos ${ }^{6}$; de tal forma que los procedimientos ineficaces o trufados de dilaciones pueden suponer la violación del art 8 $\mathrm{CEDH}^{7}$.

\section{I.2. La nueva regulación procesal de la sustracción internacional de menores}

La regulación procesal de las medidas relativas a la restitución o retorno de menores en los supuestos de sustracción internacional, hasta hace poco contenida en los arts. I90I a I909 LEC/I88I, ha sufrido recientemente una modificación muy sustancial.

La Disposición Final tercera de la Ley $15 / 2015$, de 2 de julio, de Jurisdicción Voluntaria ha introducido un nuevo Capítulo IV bis en el Título I del Libro IV de la Ley de Enjuiciamiento $\mathrm{Civil}^{8}$, integrado por los artículos 778 quáter a 778 sexies, en el que se contienen las medidas relativas a la restitución de menores en supuestos de sustracción internacional de menores; regulación que entró en vigor el 23 de julio de 2015. Esta reforma revisa muy acertadamente la opción legislativa consistente en mantener esta materia dentro del campo de la jurisdicción voluntaria y fuera del ámbito propio de los procesos contenciosos de familia. Se trata de otro de los grandes aciertos de la Ley de Jurisdicción

${ }^{4}$ Vid., por ejemplo, SSTEDH de 26 de octubre de 20I0, Raban contra Rumania (JUR 20I0।359556); de I3 de julio de 20IO, Fuşcă contra Rumania (JUR 20IO\233656); de I de diciembre de 2009, Eberhard y M contra Eslovenia (JUR 2009\473405).

${ }^{5}$ Cfr. SSTEDH de 2I de septiembre de 20I0, Mijušković contra Montenegro (TEDH 20Io\97); de I de diciembre de 2009, Eberhard y M contra Eslovenia (JUR 2009\473405).

${ }^{6}$ Vid. SSTEDH de 2I de septiembre de 20IO, Mijušković contra Montenegro (TEDH 20Iol97); de 22 de diciembre de 2009, Tapia Gasca y D. contra España (TEDH 2009\I45).

${ }^{7}$ Cfr. STEDH de I de diciembre de 2009, Eberhard y M contra Eslovenia (JUR 2009\473405). De hecho, en su Sentencia de I7 de enero de 2012 (asunto Kopf y Liberda contra Austria, JUR 20I2/I49IO), el Tribunal Europeo de Derechos Humanos ha llegado a acuñar el denominado principio de «diligencia excepcional», con el que subraya la obligación de los Estados de resolver los procedimientos sobre menores con celeridad teniendo en cuenta que el paso del tiempo puede derivar en una resolución de facto de la cuestión.

${ }^{8}$ La Ley de Jurisdicción Voluntaria ha reformado la Ley de Enjuiciamiento Civil para dotar de la adecuada coherencia interna a nuestro ordenamiento procesal, y fundamentalmente para contemplar las nuevas competencias de Letrados de la Administración de Justicia, Notarios y Registradores de la Propiedad y Mercantiles en materia de jurisdicción voluntaria. En concreto, la Disposición Final tercera modifica la Ley de Enjuiciamiento Civil en materia de: capacidad procesal (art. 8.I), condena en costas en caso de allanamiento (art. 395.I), sentencias no provisionalmente ejecutables (art. 525.I), ejecución por condena a prestación alimenticia (art. 608), procesos sobre capacidad, filiación, matrimonio y menores (arts. 748, 749, 758 769.I y 2, 777 y 782.1 ), división judicial de la herencia (arts. 790, 79I.2, 792.I y 802.I), así como la Disposición Final vigésima segunda. 
Voluntaria ${ }^{9}$ ya que en los supuestos de sustracción internacional resulta evidente que hay una controversia, derivada precisamente del traslado o retención ilícita de un menor por uno de sus progenitores en contra de la voluntad del otro. Por esta razón, dicho supuestos no pueden configurarse dogmáticamente como expedientes de jurisdicción voluntaria, sino que deben reputarse como verdaderos procesos especiales ratione materiae ${ }^{\mathrm{ro}}$.

Dicho razonamiento doctrinal no resulta en absoluto una mera discusión bizantina. De hecho, ya durante la vigencia de los arts. I90I a I909 LEC/I88I, a pesar de que el procedimiento se ubicaba formalmente en la normativa sobre jurisdicción voluntaria, se admitía siempre que hubiera oposición (es decir, en todos los supuestos, dado que el objeto de este proceso es un traslado o retención ilegítima del menor no consentida por el otro progenitor) su naturaleza material de proceso jurisdiccional civil. En este sentido resulta especialmente ilustrativo el Auto de la Audiencia Provincial de Valencia de 29 de noviembre de 2002 (JUR 2003\53822) que, al valorar si la restitución es un procedimiento de jurisdicción voluntaria o debe reputarse un proceso jurisdiccional civil, dispone en su Fundamento Jurídico segundo:

«(...) se prevé tanto la posibilidad de oposición (art. I904b) LEC/I88I) como de discusión contradictoria en el mismo acto de jurisdicción voluntaria, sin ser de aplicación el art. I8I7 LEC/I88I, 'ventilándose la oposición ante el mismo juez por los trámites del juicio verbal' (art. I907 LEC/I88I). Esta circunstancia permitiría matizar, o al menos poner en duda igualmente, la afirmación inicial de que no hay verdaderas partes en este procedimiento, máxime cuando se prevé la participación del Ministerio Público y que los 'interesados' podrán actuar bajo la dirección de abogado (art. I902 LEC/I88I). Asimismo, es incluso discutible en parte la afirmación inicial de que no produce eficacia de cosa juzgada pues, como ha señalado la doctrina, la lectura del art. I8I8.2 LEC/I88I permite hablar de una cosa juzgada formal de las resoluciones definitivas que en su seno se dicten. Con todo, se dan otras circunstancias especiales respecto de la 'jurisdicción contenciosa', como, por ejemplo, que no cabe acumulación con juicios contenciosos, lo que tampoco plantea diferencias sustanciales en cuanto es posible, en ciertos casos, que ni siquiera

\footnotetext{
${ }^{9}$ Para un estudio sistemático de la nueva Ley I5/20I5, de 2 de julio, vid. por todos LiébanA ORTIZ, J. R. y Pérez Escalona, S., Comentarios a la Ley de Jurisdicción Voluntaria, Thomson Reuters Aranzadi, Cizur Menor, 2015 .

${ }^{10}$ Vid., LiÉBANA OrTiZ, J. R., Fundamentos dogmáticos de la jurisdicción voluntaria, Iustel Madrid 20I2, pág. II9; ÍDEM, Ensayo sobre una teoría general de la jurisdicción voluntaria, Editorial Académica Española, Saarbrücken, 20I2, págs. 77-78, nota 68. En sentido contrario se ha pronunciado, no obstante, FERNÁNDEZ DE BUJÁN, A. («El anteproyecto de Ley de Jurisdicción Voluntaria y la sustracción internacional de menores», en Abogados, núm. 85, abril, págs. 28-32), para quien el procedimiento de restitución de menores debe mantenerse en el marco de la jurisdicción voluntaria por los siguientes motivos: a) la regulación actual (arts. I901 a I909 LEC/I88I) no fueron derogados en el año 2000 con la promulgación de la vigente Ley de Enjuiciamiento Civil; b) Hay mayor seguridad en que se produzca una más rápida y efectiva reintegración del menor en el marco de la jurisdicción voluntaria; en el anteproyecto y proyecto de ley de jurisdicción voluntaria de 2005 y 2006 respectivamente se preveía un incidente de oposición y la contracción en el marco del procedimiento, y su resolución en el mismo procedimiento; d) En materia de jurisdicción voluntaria son hábiles todos los días y horas sin excepción (art. I8I2 LEC/I88I) y cualquier otra actuación que se suscite fuera de los días y horas hábiles puede tramitarse y o ejecutarse por el juzgado de guardia; e) Con el procedimiento de jurisdicción voluntaria se logra la misma finalidad que en el marco de lo contencioso, con idénticas garantías y en menor espacio de tiempo, y de acuerdo con la normativa internacional aplicable en España [Reglamento CE núm. 2201/2003, del Consejo, de 27 de noviembre de 2003, relativo a la competencia, el reconocimiento y la ejecución de resoluciones judiciales en materia de matrimonial y de responsabilidad parental y Convenio de La Haya, de 25 de octubre de I980, sobre los aspectos civiles de la sustracción internacional de menores] para la restitución de los menores los Estados deben utilizar los procedimientos más expeditivos que prevea la legislación nacional.
} 
'juicios contenciosos' puedan ser acumulados entre sí, dados los requisitos de competencia, adecuación de procedimiento y hasta de conexión de pretensiones exigidos para ello.

Muy dudosa resulta igualmente la afirmación contenida en el escrito de recurso por la que en el procedimiento de jurisdicción haya carencia de solemnidad, puesto que tan solemne puede serlo como la jurisdicción contenciosa al tramitarse en buena medida por procedimientos comunes. Este Tribunal comparte (...) que las referencias al verbal contenidas en el art. I907 LEC/I88I se entienden realizadas al juicio verbal regulado en los arts. 437 y ss. LEC I/2000. En ese sentido, la Disposición Derogatoria Primera de la LEC I/2000 in fine dispone que 'en tanto no entre en vigor la Ley sobre Jurisdicción Voluntaria, las referencias al procedimiento contencioso procedente contenidas en el Libro Tercero se entenderán hechas al juicio verbal'. Siendo de aplicación, por tanto, las normas que regulan este juicio verbal, con las únicas excepciones que pudieran resultar incompatibles con la naturaleza del procedimiento de jurisdicción voluntaria. Incompatibilidad que, coincidiendo con el escrito de oposición del Ministerio Fiscal, consideramos igualmente que no concurre con la aplicación del art. 442 LEC».

En definitiva, que las medidas relativas a la restitución o retorno de menores en los supuestos de sustracción internacional, a pesar de que la Ley Orgánica I/1996, de I5 de enero, de Protección Jurídica del Menor las introdujo entre las normas reguladoras de la jurisdicción voluntaria en la Sección Segunda del Título IV del Libro III de la LEC/I88I, sin embargo tanto desde un punto de vista dogmático como desde el punto de vista de la práctica procesal se han de considerar como un proceso jurisdiccional civil especial. Así, es jurisprudencia reiterada que en los procedimientos sobre sustracción ilícita de menores son aplicables las especialidades procesales de los procesos sobre capacidad, filiación, matrimonio y menores; concretamente las particularidades señaladas en el art. 752 LEC sobre la inexistencia de preclusión para las alegaciones e introducción de hechos, en la investigación de oficio de la verdad material y en la plenitud de efectos del principio de libre valoración de la prueba ${ }^{\mathrm{II}}$.

En este sentido, como ya apuntábamos al inicio del presente subepígrafe, la Ley de Jurisdicción Voluntaria ha acertado plenamente al no regular como un expediente de esta naturaleza las medidas relativas a la restitución o retorno de menores en los supuestos de sustracción internacional y optar por incluirlas como un proceso jurisdiccional civil especial más de la Ley de Enjuiciamiento Civil. Tal y como atinadamente señala el legislador en el apartado XII de la Exposición de Motivos de la Ley de Jurisdicción Voluntaria:

«La modificación de la Ley de Enjuiciamiento Civil sirve también para actualizar el procedimiento para el retorno de los menores en los casos de sustracción internacional, al objeto de asegurar una mejor protección del menor y de sus derechos. Esta reforma revisa la opción legislativa consistente en mantener esta materia dentro del campo de la jurisdicción voluntaria y fuera del ámbito propio de los procesos contenciosos de familia, pues se trata de procesos que poco tienen que ver con las normas relativas a la jurisdicción voluntaria. Por este motivo se aborda ahora su regulación como un proceso especial y con sustantividad propia, a continuación de los procesos matrimoniales y de menores en la Ley de Enjuiciamiento Civil».

${ }^{\text {II }}$ Así lo han sostenido, por todas, la SAP Barcelona de I de septiembre de 2010 (JUR 20I0।387472), FJ $2^{\circ}$ y el AAP Murcia de io de junio de 20II (AC 20II \I376), FJ $2^{\circ}$. 
El objeto de las páginas que siguen es analizar el nuevo proceso relativo a la restitución o retorno de menores en los supuestos de sustracción internacional, regulado en los arts. 778 quáter a 778 sexies LEC, por cuanto, como veremos, es el procedimiento interno previsto para implementar de la forma más eficaz y rápida posible las obligaciones que el Reino de España ha asumido al ratificar los instrumentos internacionales sobre aspectos civiles de la sustracción internacional de menores ${ }^{\mathrm{T2}}$.

\section{II. Ámbito de aplicación del proceso relativo a la restitución o retorno de menores en los supuestos de sustracción internacional}

La cuestión sobre si la decisión del traslado de domicilio de un menor corresponde en exclusiva al progenitor custodio o si, por el contrario, es una facultad inherente al ejercicio de la patria potestad ha sido finalmente resuelta por la STS de 26 de octubre de $20 \mathrm{I2}$ (RJ 20I2\9730) en el sentido de que para proceder al cambio de domicilio de un menor es necesario el acuerdo de ambos progenitores o, en su defecto, decisión judicial, sin que quepa la decisión unilateralmente del progenitor custodio, al ser una decisión que se integra en el contenido de la patria potestad ${ }^{13}$. Pues bien, el proceso relativo a la restitución

\footnotetext{
${ }^{12}$ Nos referimos, en concreto, a la Convención de los Derechos del Niño de 20 de noviembre de I989; el Convenio Europeo de Derechos Humanos; el Convenio de La Haya, de 25 de octubre de i980, sobre los aspectos civiles de la sustracción internacional de menores; el Convenio de Luxemburgo, de 20 de mayo de I980, sobre reconocimiento y ejecución de decisiones en materia de custodia de menores y restablecimiento de dicha custodia; el Convenio del Consejo de Europa, de I5 de mayo de 2003 , sobre las relaciones personales del menor (cuya rúbrica por el Reino de España fue autorizada por el Consejo de Ministros el II de septiembre de 20I5); el Reglamento (CE) 2201/2003 del Consejo, de 27 de noviembre, relativo a la competencia, el reconocimiento y la ejecución de resoluciones judiciales en materia matrimonial y de responsabilidad parental; el Convenio entre el Reino de España y el Reino de Marruecos, de 30 de mayo de I997, sobre asistencia judicial, reconocimiento y ejecución de resoluciones judiciales en materia de derecho de custodia, derecho de visitas y devolución de menores.
}

${ }^{13}$ Resulta muy ilustrativo reproducir el Fundamento Jurídico $2^{\circ}$ de la Sentencia mencionada en el texto principal: «Las acciones y responsabilidades que derivan de la patria potestad corresponden a ambos padres de tal forma que cualquiera de ellos, tanto el que tiene la guarda como el que no la conserva, puede actuar en relación a sus hijos una posición activa que no solo implica colaborar con el otro, sino participar en la toma de decisiones fundamentales al interés superior del menor. Una de ellas la que concierne a su traslado o desplazamiento en cuanto le aparta de su entorno habitual e incumple el derecho de relacionarse con el padre o madre no custodio. La patria potestad, dice el art. I56 CC, se ejercerá conjuntamente por ambos progenitores o por uno solo con el consentimiento expreso o tácito del otro. En caso de desacuerdo, cualquiera de los dos podrá acudir al Juez quien, después de oír a ambos y al hijo si tuviera suficiente juicio y, en todo caso, si fuera mayor de doce años, atribuirá sin ulterior recurso la facultad de decidir al padre o a la madre. Supone que todos los derechos y deberes que entraña la patria potestad se han de ejercer siempre de común acuerdo por ambos progenitores y de que, en caso de desacuerdo, será el Juez quien determine cuál de los dos ha de ejercer todas o algunas de las facultades que la patria potestad comporta y por cuanto tiempo, pero sin que esta intervención judicial sobre los desacuerdos de los progenitores implique la supresión de estos derechos-deberes de la patria potestad que se ejercitan en un plano de igualdad y no de subordinación. La regla general es el ejercicio conjunto y la excepción la atribución de todas o alguna de las facultades que comporta la patria potestad a uno solo de los progenitores. Pues bien, la guarda y custodia de los menores deriva de la patria potestad y de la patria potestad, entre otras cosas, deriva la fijación del domicilio familiar, según dispone el art. 70 CC, para dar cumplimiento a lo previsto en el art. $68 \mathrm{CC}$, respecto de la obligación de vivir juntos. La ruptura matrimonial deja sin efecto la convivencia y obliga a los progenitores a ponerse de acuerdo para el ejercicio de alguna de estas facultades que traen causa de la patria potestad, entre otra la de fijar el nuevo domicilio y, como consecuencia, el de los hijos que se integran dentro del grupo familiar afectado por la ruptura coincidente por lo general con el de quien ostenta la guarda y custodia. Estamos, sin duda, ante una de las decisiones más importantes que pueden adoptarse en la vida del menor y de la propia familia, que deberá tener sustento en el acuerdo de los progenitores o en la decisión de uno de ellos consentida expresa o tácitamente por el otro, y solo en defecto de este acuerdo corresponde al juez resolver lo que proceda previa identificación de los bienes y derechos en conflicto a fin de poder calibrar de una forma ponderada la necesidad y proporcionalidad de la medida adoptada, sin condicionarla al propio conflicto que motiva la ruptura. Es cierto que la CE, en su art. I9, determina el derecho de los españoles a elegir libremente su residencia, y a salir de España en los términos que la ley establezca. Pero el problema no es éste. El problema se suscita sobre la procedencia o improcedencia de pasar la 
de menores en los supuestos de sustracción internacional viene a dar la cobertura jurídicoprocesal a esta cuestión en los supuestos en que existe un elemento internacional.

En efecto, este proceso jurisdiccional de nuevo cuño tiene por objeto la regulación del procedimiento a seguir en el caso en que se pretenda la restitución de un menor o su retorno al lugar de procedencia siempre que, encontrándose en España, haya sido objeto de un traslado o retención ilícita a la que se aplique un Convenio Internacional del que nuestro país sea parte o las normas de Derecho comunitario aplicables en la materia (art. 778 quáter. I LEC). Es decir, este proceso especial será de aplicación cualquiera que sea el Convenio, de entre los suscritos por el Reino de España, que se alegue (Convenio de Luxemburgo, Convenio de La Haya, Reglamento Bruselas II bis y Convenio Bilateral con Marruecos), y sólo en cuando se alegue alguno de ellos.

Sensu contrario, el proceso especial previsto en los arts. 778 quáter a 778 sexies LEC no será aplicable cuando el Estado requirente no sea parte en ninguno de los convenios sobre sustracción internacional de menores antedichos que ha ratificado España, tal y como expresamente dispone el inciso segundo del art. 778 quáter.I LEC ${ }^{\mathrm{I}}$. En estos casos será necesario acudir a los mecanismos generales de cooperación judicial internacional y de exequatur previstos en la Ley de cooperación jurídica internacional en materia civil.

Ello no obstante, para la cabal comprensión del ámbito objetivo de aplicación de este nuevo proceso especial debe definirse claramente qué se debe entender por traslado ilícito y por retención del menor a los efectos de concluir adecuadamente el ámbito de aplicación del mismo. De conformidad con los arts. 3 del Convenio de La Haya y 2.II del Reglamento Bruselas II bis, el traslado o la retención de un menor se consideran ilícitos:

a) cuando se hayan producido con infracción de un derecho de custodia atribuido por resolución judicial, por ministerio de la ley o por un acuerdo con efectos jurídicos con arreglo al Derecho vigente en el Estado en donde el menor tenía su residencia habitual inmediatamente antes de su traslado o retención; y

b) cuando este derecho se ejercía de forma efectiva, separada o conjuntamente, en el momento del traslado o de la retención, o se habría ejercido de no haberse producido dicho traslado o retención.

Ahora bien, el ámbito de aplicación del proceso relativo a la restitución o retorno de menores en los supuestos de sustracción internacional no quedaría adecuadamente delimitado si no realizamos siquiera un sucinto análisis del ámbito subjetivo de aplicación de las normas convencionales internacionales y de derecho interno que precisamente justifican el objeto del proceso civil especial que motiva el presente estudio.

menor a residir en otro lugar, lo que puede comportar un cambio radical tanto de su entorno social como parental, con problemas de adaptación. De afectar el cambio de residencia a los intereses de la menor, que deben de ser preferentemente tutelados, podría conllevar, un cambio de la guarda y custodia».

${ }^{14}$ En este sentido ya se pronunciado los AAP Cuenca de Io de junio de 2004 (JUR 2004\I79694), FJ 2 $2^{\text {o; } y ~}$ Málaga de I5 de diciembre de i997. 
II.I. Convenio sobre los aspectos civiles de la sustracción internacional de menores, hecho en La Haya el 25 de octubre de $1980^{15}$.

El Convenio de La Haya es el instrumento internacional más importante en materia de sustracción internacional de menores $^{\mathrm{I} 6}$, y persigue una doble finalidad: I) garantizar la restitución inmediata de los menores trasladados o retenidos de manera ilícita en cualquier Estado contratante, y 2) velar por que los derechos de custodia y de visita vigentes en uno de los Estados contratantes se respeten en los demás Estados contratantes.

La filosofía del Convenio parte de la preservación del interés del menor identificado con la permanencia en su entorno vital y, consecuentemente en su inmediato retorno cuando es desplazado a otro Estado. El Convenio se inspira en el principio solve et repete: primero se retorna al menor y luego, en su caso, se discute sobre a quién corresponden los derechos de guarda y visita y el derecho a decidir sobre la residencia del menor. En este sentido, resulta muy clarificadora la Profa. Pérez Vera al decir:

«Dado que un factor característico de las situaciones consideradas, reside en el hecho de que el sustractor pretende que su acción sea legalizada por las autoridades competentes del Estado de refugio, un medio eficaz de disuadirle, consiste en que sus acciones se vean privadas de toda consecuencia práctica y jurídica. Para alcanzar este objetivo, el Convenio consagra en primer lugar entre sus objetivos el restablecimiento del status quo mediante la 'restitución inmediata de los menores trasladados o retenidos de forma ilícita en cualquier Estado contratante’ ${ }^{\mathrm{I}}$.

Pues bien, el Convenio de La Haya atribuye a las Autoridades Centrales de cada uno de los Estados parte la misión de colaborar entre sí y promover la colaboración entre las autoridades competentes en sus respectivos Estados. En el caso de España, la Autoridad Central es el Ministerio de Justicia y, en concreto, dichas funciones corresponden a la Subdirección General de Cooperación Jurídica Internacional ${ }^{18}$.

Sin embargo, la Autoridad central no tiene el monopolio en el ejercicio de las acciones de restitución de los menores sino que, conforme al art. 29 del Convenio, el progenitor puede ejercitar directamente la incoación del procedimiento que, en todo caso, se regirán los por principios del superior interés del menor, celeridad, prohibición de decisión sobre el fondo y especialización de los operadores jurídicos.

\footnotetext{
${ }^{15}$ Aprobado por Instrumento de ratificación publicado en el BOE núm. 202, de 24 de agosto de I987.

${ }^{16}$ En efecto, el número de Estados miembros del Convenio aumenta cada año, precisamente porque tanto a nivel personal como estatal se reconoce su aportación al superior interés del menor sustraído o retenido ilícitamente. De acuerdo con los datos facilitados por la Hague Conference on Private Internacional Law, (http://www.hcch.net) en la actualidad han ratificado el Convenio de La Haya sobre sustracción internacional de menores 77 países, de los cuales 25 han sido aceptados por España. Para un estudio en profundidad de este Convenio cfr., por todos, PÉREz VerA, E., Algunas consideraciones sobre la aplicación en España del Convenio de la Conferencia de La Haya sobre aspectos civiles de la sustracción internacional de menores, de 25 de octubre de 1980, Madrid, 2002, I8 pags., presentada en la reunión de expertos gubernamentales sobre sustracción internacional de menores por parte de uno de sus padres, celebrada en Montevideo el I2 y I3 de agosto de 2002. (http://www.mimdes.gob.pe/dgnna/sinna/documentos.htm)

${ }^{17}$ Cfr. Informe explicativo del Convenio núm. XVIII de la conferencia de La Haya sobre los aspectos civiles de la sustracción de menores, cit., pág. 4 .

${ }^{18}$ Así se prevé en el art. 6 del Real Decreto 453/2012, de 5 de marzo, por el que se desarrolla la estructura orgánica básica del Ministerio de Justicia.
} 
Respecto del ámbito subjetivo de aplicación, el art. 4 del Convenio establece que si un niño menor de $\mathrm{I} 6$ años es trasladado de su residencia habitual a otro país, violando un derecho de custodia atribuido a la otra persona o a una institución, el menor debe regresar al Estado en que tuviera su residencia habitual en el momento de su sustracción ilegal; siendo el competente para decidir sobre su guardia y custodia el Juez de dicho Estado.

El Convenio de La Haya considera que un joven con más de i6 años, pese a que conforme al Convenio de los Derechos del Niño es menor de edad, difícilmente se le puede imponer coactivamente una resolución sobre su lugar de residencia. Además, el informe explicativo del Convenio especifica que no se podrá llevar a cabo o aprobar ninguna acción o resolución respecto a un menor tras su decimosexto cumpleaños.

Por lo que respecta al sujeto activo de la sustracción, aunque el Convenio no contiene ninguna disposición expresa al respecto, cabe realizar dos consideraciones para clarificar este aspecto del ámbito de aplicación ratione personae del Convenio. La primera se refiere a las personas físicas que pueden ser responsables del traslado o del no retorno de un menor. Sobre tal cuestión, el Convenio mantiene el punto de vista adoptado por la Comisión especial de no atribuir dichas acciones exclusivamente a los progenitores. Y es que, siendo el concepto de familia más o menos amplio según las distintas concepciones culturales, es preferible atenerse a una visión amplia que permita, por ejemplo, calificar de sustracción de un menor, de acuerdo con el Convenio, los traslados realizados por un abuelo o un padre adoptivo.

II.2. Convenio entre el Reino de España y el Reino de Marruecos sobre asistencia judicial, reconocimiento y ejecución de resoluciones judiciales en materia de derecho de custodia y derecho de visita y devolución de menores, hecho en Madrid el 30 de mayo de $1997^{\text {19 }}$

Este es el único Convenio bilateral que existe en la actualidad sobre esta materia y su importancia radica no sólo en que Marruecos hasta el 9 de marzo de 20 Io no se adhirió al Convenio de La Haya sobre la materia, sino fundamentalmente en la cercanía con este Estado y los múltiples intercambios personales existentes que terminan en matrimonios mixtos.

Este Convenio bilateral se aplica a todo menor no emancipado que tenga la nacionalidad de uno de los dos países firmantes y su objeto es triple: en primer lugar, garantizar la devolución de los menores desplazados o retenidos, ilegalmente, a uno de los dos Estados; en segundo lugar, hacer que se reconozcan y ejecuten las resoluciones judiciales relativas a la custodia y al derecho de visita, dictadas en uno de los dos Estados contratantes en el territorio del otro Estado; y en tercer lugar, favorecer el libre ejercicio del derecho de visita en el territorio de ambos Estados.

El Convenio con Marruecos sigue el mismo sistema de Autoridades Centrales que el Convenio de La Haya ya analizado, dejando abierta la posibilidad de que los particulares

\footnotetext{
${ }^{19}$ En el BOE núm. I50, de 24 de junio de I997, se publicó el texto para su aplicación provisional, entrando efectivamente en vigor el ide julio de I999, primer día del segundo mes siguiente a la fecha de la última notificación cruzada entre las Partes comunicando el cumplimiento de las respectivas formalidades constitucionales requeridas por el art. 22 del Convenio, tras su publicación para conocimiento general en el BOE núm. I5I, de 25 de junio de I999.
} 
actúen por sí, al margen de aquellas. En todo caso, tras la ratificación por Marruecos del Convenio de La Haya sobre sustracción internacional de menores podrá aplicarse en cada caso la norma más favorable para lograr el retorno del menor y para asegurar la protección efectiva de su interés, lo que normalmente conducirá a la aplicación del Convenio multinacional.

II.3. Convenio del Consejo de Europa sobre reconocimiento y ejecución de decisiones en materia de custodia de menores y restablecimiento de dicha custodia, hecho en Luxemburgo el 20 de mayo de $1980^{20}$.

Este Convenio permite que una sentencia dictada en un Estado parte, pueda ser reconocida y ejecutada en el Estado donde un menor ha sido trasladado ilícitamente, o en el que se niega el desarrollo del derecho de visita. Frente a un exequátur normal, el Convenio de Luxemburgo permite que el reconocimiento y ejecución se lleven a cabo con mayor rapidez y sin las formalidades que se exigen en el procedimiento general.

El Convenio de Luxemburgo parte también de la limitación de las sustracciones a menores de 16 años, si bien especifica que el traslado puede ser ilícito por ejecutarse con infracción de una resolución previa en materia de custodia; por no retornar al menor tras haber expirado el período de tiempo permitido para el ejercicio de un derecho de visita $u$ otra estancia temporal o por haber sido declarado ilícito con posterioridad.

Por otra parte, el Convenio de Luxemburgo y el Convenio de La Haya son complementarios aunque la Autoridad Central española suele decantarse por aplicar preferentemente el cauce del Convenio de La Haya, por ser más efectivo y haber sido ratificado por mayor número de países. Además, en la actualidad resulta de aplicación preferente la normativa comunitaria que mencionaremos a continuación, por lo que la aplicación real del Convenio de Luxemburgo en esta materia suele se residual.

II.4. Reglamento (CE) núm. 2201/2003, del Consejo, de 27 de noviembre de 2003, relativo a la competencia, el reconocimiento y la ejecución de resoluciones judiciales en materia matrimonial y de responsabilidad parental ${ }^{2 \mathrm{I}}$

El Reglamento 220I/2003, también llamado Bruselas II bis, es una norma comunitaria de carácter general y unificador, y directamente aplicable en todos los países miembros, que profundiza en la necesidad de lograr el retorno inmediato del menor ilícitamente trasladado, consagrando los principios del superior interés del menor ${ }^{22}$ y de celeridad $^{23}$, además del de cooperación entre las autoridades de los Estados, reforzando y complementando el Convenio de La Haya sobre los aspectos civiles de la sustracción de

${ }^{20}$ Aprobado por Instrumento de ratificación publicado en el BOE núm. 2Io, de I de septiembre de I984. Para información adicional sobre el Convenio de Luxemburgo de I980 puede consultarse la web del Consejo de Europa http://www.coe.int/en/web/conventions/full-list/-/conventions/treaty/I05/signatures

${ }^{21}$ Publicado en el Diario Oficial de la Comunidad Europea de 23 de diciembre de 2003, Serie L 338, siendo aplicable desde el I de marzo de 2005 a todos los países de la Unión Europea con la única excepción de Dinamarca. Para un estudio en profundidad sobre en esta materia cfr. GonZÁLVEZ VICENTE, P., «La sustracción internacional de menores y su nueva regulación», Revista jurídica de Castilla Y León, núm. II, 2007, págs. 67-I24.

${ }^{22}$ Así lo ha sostenido, por ejemplo, el AAP Madrid de 3 de julio de 2007 (JUR 2007\308779), FJ $2^{\circ}$.

${ }^{23}$ Vid. en este sentido SAP Málaga de iI de septiembre de 2007 (AC 2007\2085), FJ $2^{\circ}$. 
menores que hemos analizado supra en el subepígrafe 2.I, lo cual constituye una novedad en orden a garantizar el clima de confianza mutua comunitario para facilitar la ejecución de resoluciones dictadas por los Estados miembros de la Unión Europea, sin necesidad de acudir al trámite del exequatur, para la efectividad material de las decisiones del retorno del menor y, en suma, para resolver las cuestiones relativas a la custodia y al derecho de visita

El Reglamento Bruselas II bis no define una edad máxima para los menores sujetos pasivos de la sustracción ilegal, por lo que resulta razonable considerar que existe una remisión tácita al Convenio de La Haya de I980 de tal forma que no debe aplicarse más allá de los i6 años de edad. Debe señalarse, igualmente, que no se tiene en cuanta la nacionalidad, sino la residencia habitual en un país comunitario por lo que el Reglamento Bruselas II bis resulta aplicable a los supuestos de sustracciones intracomunitarias de menores, incluso cuando éstos no ostenten nacionalidad comunitaria.

En cuanto al ámbito territorial, tomando como base el Convenio de La Haya de I980 sobre la materia, se establece que en caso de traslado o retención ilícitos de un menor, los órganos jurisdiccionales del Estado miembro en que el residía habitualmente el menor inmediatamente antes del traslado o retención ilícitos conservarán su competencia hasta que el menor haya adquirido su residencia habitual en otro Estado y toda persona, institución $u$ organismo que tenga el derecho de custodia haya dado su conformidad al traslado o a la retención o bien el menor, habiendo residido en ese otro Estado miembro durante un periodo mínimo de un año estén integrado en su nuevo entorno y cumpla una serie de condiciones. Ahora bien, en materia de restitución del menor establece una serie de reglas especiales que alteran o modifican el régimen convencional de La Haya ${ }^{24}$.

\section{II.5. La cooperación jurídica internacional y el procedimiento de exequatur}

Según dispone el apartado segundo del art. 778 quáter.I LEC, el proceso relativo a la restitución o retorno de menores en los supuestos de sustracción internacional «no será de aplicación a los supuestos en los que el menor procediera de un Estado que no forma parte de la Unión Europea ni sea parte de algún convenio internacional» de los analizados en los subepígrafes precedentes. En estos casos será necesario acudir a los mecanismos generales de cooperación judicial internacional y de exequatur previstos en la Ley 29/2015, de 30 de julio, de cooperación jurídica internacional en materia civil.

Así, el régimen general de la cooperación jurídica internacional, regulado en los arts. 20 a 36 de la Ley 29/2015, se aplica a las solicitudes de cooperación jurídica en materia de notificación y traslado de documentos judiciales y extrajudiciales y respecto a la obtención y práctica de la prueba.

Pero lo verdaderamente importante en los supuestos de sustracción internacional de menores que no proceden de un Estado de la Unión Europea ni es parte de alguno de los Convenios internacionales ya analizado es el nuevo procedimiento de exequatur (regulado en los arts. 52 a 55 Ley 29/2015), es decir, el procedimiento para declarar a título principal el reconocimiento o denegación del reconocimiento de una resolución judicial extranjera y, en

${ }^{24}$ Para un estudio exhaustivo del ámbito de aplicación del Reglamento (CE) núm. 2201/2003 vid., por ejemplo, QuiÑones EsCÁMEZ, A., «¿Cuándo se aplica el Reglamento Bruselas II bis? El TJCE se pronuncia sobre su ámbito de aplicación», Revista de Derecho Comunitario Europeo, núm. 29, 2008, págs. 457-482. 
su caso, para autorizar su ejecución; estableciéndose normas de competencia y asistencia jurídica gratuita y detallando el proceso y los recursos admisibles ${ }^{25}$.

Cabe concluir señalando que, al igual que respecto del régimen convencional internacional ya analizado, la Ley de cooperación jurídica internacional en materia civil designa al Ministerio de Justicia como Autoridad Central española, cuyas funciones, desempeñadas en concreto por la Subdirección General de Cooperación Jurídica Internacional $^{26}$, coinciden en gran medida con las que se le atribuyen en virtud de tratados y acuerdos internacionales y las normas de la Unión Europea, y han de facilitar la cooperación jurídica internacional tanto si la requiere una autoridad española como si es española la autoridad requerida.

\section{Competencia, legitimación y postulación}

\section{III.I. Órgano jurisdiccional competente}

En los procesos relativos a la restitución o retorno de menores en los supuestos de sustracción internacional será competente el Juzgado de Primera Instancia de la capital de la provincia, de Ceuta o Melilla, con competencias en materia de derecho de familia, en cuya circunscripción se halle el menor que haya sido objeto de un traslado o retención ilícitos, si lo hubiere y, en su defecto, al que por turno de reparto corresponda. Además, por aplicación del principio de seguridad y para la mejor protección del menor, el Tribunal examinará de oficio su competencia (art. 778 quáter.2 LEC).

La nueva regulación de la competencia judicial resulta acertada, no ya sólo por su claridad y precisión técnica, sino también porque establece unos fueros que favorecen la necesaria especialización y concentración en esta materia, dado el interés superior del menor que rige en esta materia; lo que además está en línea con los principios de rapidez y coherencia que postulan tanto la Guía de Buenas Prácticas del Convenio de La Haya sobre aspectos civiles de la sustracción internacional como la y la Guía práctica para la aplicación del nuevo Reglamento Bruselas II bis para la determinación de las autoridades judiciales o

\footnotetext{
${ }^{25}$ Por lo que respecta al procedimiento de exequatur se simplifica y moderniza notablemente, permitiendo acumular en un mismo escrito tanto la demanda de exequátur (en donde además cualquiera de las partes podrá solicitar la asistencia jurídica gratuita) como la petición de ejecución; escrito que deberá ajustarse a los principios de objeto y contenido de la demanda de los arts. 399 y SS. LEC, si bien la petición de ejecución no se tramitará hasta que se haya dictado resolución decretando el exequátur. Se permite también la solicitud, igualmente en aquel primer escrito, de adopción de medidas cautelares, que se sujetarán a lo previsto en los artículos 72I a 747 LEC. Los documentos que deberán acompañar la demanda son: (i) original o copia auténtica, legalizada o apostillada, de la resolución extranjera; (ii) documento acreditativo de la firmeza, pudiendo constar la misma en la propia resolución, lo que supone una garantía legal a la hasta ahora facultad potestativa de los Juzgados de solicitar en documento independiente dicha firmeza, so pena de no admitir a trámite el exequátur; y por último, (iii) las traducciones, que atendiendo al artículo I44.2 LEC podrán ser no juradas, sin perjuicio de que la contraparte pueda impugnarlas por tenerlas como no fieles. Una vez admitido el escrito de demanda, se dará traslado de la misma a la otra parte, quien podrá oponerse en el plazo de treinta días sobre la base de tres fundamentos numerus clausus: (a) impugnar la autenticidad de la resolución, (b) corregir el emplazamiento al demandado, o (c) corregir la firmeza y/o fuerza ejecutiva de la resolución. En cualquier caso, el Ministerio Fiscal se personará siempre en procesos de exequátur y hará las manifestaciones que considere oportunas. Contra el auto de exequátur se podrá interponer recurso de apelación ex arts. 455 a 465 LEC, y será elevado a la Audiencia Provincial competente. Contra esta resolución en segunda instancia, cabrá recurso extraordinario por infracción procesal (arts. 468 a 476 LEC) y casación (arts. 477 a 489 LEC).

${ }^{26}$ Así se prevé en el art. 6 del Real Decreto 453/20I2, de 5 de marzo, por el que se desarrolla la estructura orgánica básica del Ministerio de Justicia.
} 
administrativas nacional competentes para decidir sobre solicitudes de decisión de retorno en dicho marco convencional internacional.

En efecto, La claridad de la norma evita también posibles dudas sobre la competencia en los casos en los que por instar la restitución el propio progenitor no intervenga la Abogacía del Estado: también en estos casos será competente el Juzgado de Primera Instancia de la capital.

El carácter preferente debe llevar a atribuir competencia al Juzgado de Guardia en caso de inicio de actuaciones en días inhábiles. Será aplicable el art. 70 LEC en relación con el art. 42.5 del Acuerdo Reglamentario I/2005, de 27 de abril, del Pleno del Consejo General del Poder Judicial; ello siempre, claro está, que no exista en el concreto Partido Judicial el servicio especial dentro de la jurisdicción civil que prevé el art. 42.6 del Acuerdo Reglamentario I/2005.

Conforme al art. 42.5 del Acuerdo Reglamentario I/2005, el Juez que desempeñe en cada circunscripción el servicio de guardia conocerá también, en idéntico cometido de sustitución, de las actuaciones urgentes e inaplazables que se susciten en el ámbito de la Oficina del Registro Civil así como de las atribuidas a los Jueces Decanos en el art. 70 LEC que, como es sabido, pueden, a instancia de parte, adoptar las medidas urgentes en los asuntos no repartidos cuando, de no hacerlo, pudiera quebrantarse algún derecho o producirse algún perjuicio grave e irreparable.

A mayor abundamiento, según dispone el art. 778 quinquies.3 LEC, cuando el menor no fuera hallado en el lugar indicado en la demanda, y si, tras la realización de las correspondientes averiguaciones por el Letrado de la Administración de Justicia sobre su domicilio o residencia, éstas son infructuosas, se archivará provisionalmente el procedimiento hasta ser encontrado.

Por el contrario, si el menor fuera hallado en otra provincia, el Letrado de la Administración de Justicia, previa audiencia del Ministerio Fiscal y de las partes personadas por el plazo de un día, dará cuenta al Juez para que resuelva al día siguiente lo que proceda mediante auto, remitiendo, en su caso, las actuaciones al Tribunal que considere territorialmente competente y emplazando a las partes para que comparezcan ante el mismo dentro del plazo de los tres días siguientes.

Así, el desplazamiento del menor a otra provincia no supone la modificación automática de la competencia; al contrario, el Juez deberá decidir si continúa conociendo del asunto o si lo remite al Juzgado de la capital de provincia a la que se ha desplazado el menor.

Ahora bien, en atención al principio de celeridad que informa este proceso especial, lo razonable es que se promueva la perpetuatio iurisdictionis del Juez inicialmente competente cuando las circunstancias concurrentes puedan frustrar dicha celeridad; máxime teniendo en cuenta que de lo contrario podría condenarse a España por dilaciones indebidas dados los intereses en juego en este proceso ${ }^{27}$.

\footnotetext{
${ }^{27}$ A este respecto cabe recordar que la STEDH de 8 de enero de 2003, PP contra Polonia, condena a ésta por violación del derecho del demandante al respeto a su vida familiar por no haberse adoptado sin dilación todas las medidas que cabía razonablemente esperar para ejecutar la orden de retorno de las niñas y ejecutar el derecho de visita del demandante. Para el Tribunal Europeo de Derecho Humanos el paso del tiempo puede tener consecuencias irremediables para la relación entre el menor y el padre que no vive con su hijo.
} 


\section{III.2. Legitimación y postulación}

Por lo que se refiere a la legitimación, podrán promover el procedimiento la persona, institución $u$ organismo que tenga atribuida la guarda y custodia o un régimen de estancia o visitas, relación o comunicación del menor, la Autoridad Central Española encargada del cumplimiento de las obligaciones impuestas por el correspondiente convenio, en su caso, y, en representación de ésta, la persona que designe dicha autoridad (art. 778 quáter.3 LEC).

Existe, por lo tanto, una legitimación activa doble: la del titular custodio por sí o la del titular custodio a través de la Autoridad Central española, que a su vez actúa por medio de los abogados del Estado.

A efectos de la legitimación, qué sea el derecho de custodia habrá de ser interpretado a la luz de las previsiones del Convenio internacional cuya aplicación se solicite. En concreto, el Convenio de La Haya sobre aspectos civiles de la sustracción internacional de menores no establece una definición al respecto, pero sí configura un contenido mínimo del derecho de custodia al disponer en su art. 5.a) que comprenderá el derecho relativo al cuidado de la persona del menor y en particular el de decidir sobre su lugar de residencia. A este respecto, la jurisprudencia mayoritaria considera que aunque el traslado de residencia se lleve a cabo por el progenitor al que se había atribuido la guarda y custodia, si conforme al Derecho del país de origen la facultad de decidir sobre la residencia del menor corresponde conjuntamente a ambos progenitores, habrá de entenderse que el autor del traslado ha incurrido en sustracción internacional y por tanto, a salvo la posible concurrencia de excepciones, procede acordar el retorno ${ }^{28}$.

Desde el punto de vista de la legitimación pasiva, la tendrá el progenitor o familiar autor del traslado considerado ilegal.

En cuanto a la postulación procesal, el art. 778 quáter.4 LEC establece que las partes deberán actuar con asistencia de Abogado y representadas por Procurador. La intervención de la Abogacía del Estado, cuando proceda a instancia de la Autoridad Central española, cesará desde el momento en que el solicitante de la restitución o del retorno comparezca en el proceso con su propio Abogado y Procurador.

El reconocimiento expreso de la obligatoriedad de la asistencia letrada y la representación mediante procurador supone otro de los aciertos de la regulación del nuevo proceso relativo a la restitución o retorno de menores en los supuestos de sustracción internacional puesto que se trata de una materia tremendamente compleja en la que, además, están en juego los derechos e intereses de menores, por lo que resulta muy bienvenida la exigencia de requisitos de postulación ${ }^{29}$.

\footnotetext{
${ }^{28}$ En este sentido se han pronunciado, por ejemplo, las SSAP de Barcelona de I de septiembre de 2010 (JUR 20IO।387472), FJ $4^{\circ}$; de Barcelona de I de octubre de 20I3 (JUR 20I3\35434I), FJ $3^{\circ}$; de Málaga de I de abril de

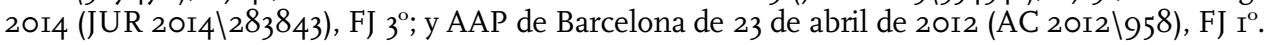

${ }_{29}$ Se modifica así el erróneo régimen procesal contenido en los arts. I902 a I909 LEC/I88I que, al incardinarse erradamente entre los actos de jurisdicción voluntaria en los que no era necesaria la asistencia de Letrado ni la representación por procurador (ex arts. IO.I y I0.3 LEC/I88I), hurtó la exigencia de requisitos de postulación a este procedimiento al guardar silencio sobre esta cuestión, a pesar de la controversia patente entre las partes y de los superiores intereses del menor en juego.
} 


\section{III.3. La intervención del Ministerio Fiscal}

El Ministerio Fiscal no tiene legitimación para promover por sí el procedimiento, aunque sí tiene la consideración de parte necesaria en el mismo. Puesto que el objeto de este proceso especial gira en torno a los derechos e intereses de los menores, todas las actuaciones en los procesos relativos a la restitución o retorno de menores en los supuestos de sustracción internacional se practicarán siempre con intervención del Fiscal, que intervendrá en defensa del interés del menor cualquiera que sea la persona o entidad que promueva la restitución (arg. ex art. 3.7 del Estatuto Orgánico del Ministerio Fiscal). Además, habiéndose incardinado el proceso especial que estamos estudiando en el Título I del Libro IV de la Ley de Enjuiciamiento Civil, debe recordase también que el art. 749.2 da entrada al Fiscal en los procedimientos sobre capacidad, filiación, matrimonio o menores, «siempre que alguno de los interesados en el procedimiento sea menor».

A mayor abundamiento, el art. 749.I LEC, en su redacción dada por la Ley de Jurisdicción Voluntaria, reconoce expresamente la legitimación del Fiscal al establecer que «en los procesos (...) de sustracción internacional de menores (...) será siempre parte el Ministerio Fiscal, aunque no haya sido promotor de los mismos ni deba, conforme a la Ley, asumir la defensa de alguna de las partes. El Ministerio Fiscal velará durante todo el proceso por la salvaguardia del interés superior de la persona afectada».

Tal y como ha puesto de manifiesto la Fiscalía General del Estado en su Circular $6 / 2015$, sobre aspectos civiles de la sustracción internacional de menores, en los procesos relativos a la restitución o retorno de menores en los supuestos de sustracción internacional el Fiscal interviene como parte imparcial, guardián de la legalidad y defensor de los derechos del menor, pero no asume la función de garantizar el retorno de los menores trasladados ilícitamente a España puesto que, a tales fines, ya se comisiona al abogado del Estado como representante de la Autoridad Central y garante del cumplimiento de las obligaciones de Derecho Internacional asumidas por España.

Así pues, al Fiscal se le encomienda asegurar el respeto al superior interés del menor. Conforme al marco convencional internacional, en abstracto y como principio general, ese interés se identifica con el retorno al lugar de procedencia, donde el menor tenía su residencia habitual y donde se ha quebrantado el statu quo. Pero más allá de ese principio general, el Fiscal debe llevar a cabo un cuidadoso examen de las concretas circunstancias concurrentes, pues las mismas pueden exigir otra posición procesal, partiendo de que la concreción del «interés del menor» es incompatible con generalizaciones abstractas, debiendo realizarse ad casum. La propia normativa convencional permite esa singularización al incorporar excepciones a la decisión de retorno, que precisamente se basan en la necesidad de salvaguardar el superior interés del menor y que, por tal motivo, cabe que sean planteadas autónomamente por el Fiscal cuando las excepciones se basen en la apreciación de que existe un grave riesgo físico o psíquico o cuando de cualquier otra manera se entienda que el retorno puede poner al menor en una situación intolerable o cuando la devolución no fuera posible en atención a los principios fundamentales de España en materia de protección de los derechos humanos y de las libertades fundamentales.

Igualmente, el Ministerio Fiscal está legitimado para proponer prueba en orden a acreditar o descartar la concurrencia de los presupuestos de las excepciones a la restitución 
y para promover la adopción de medidas cautelares, así como para apelar la resolución que decida sobre la restitución del menor, tanto si se acuerda el retorno como si se deniega.

\section{Procedimiento para la restitución o retorno de menores en los supuestos de sustracción internacional}

\section{IV.I. Normas generales del procedimiento}

El art. 778 quater LEC establece una serie de normas general del procedimiento con el objeto de proteger en todo caso el interés superior del menor, que deben ser tenidas siempre en cuenta.

$\mathrm{I}^{\mathrm{a}}$ El procedimiento tendrá carácter urgente y preferente. Deberá realizarse, en ambas instancias, si las hubiere, en el inexcusable plazo total de seis semanas desde la fecha de la presentación de la solicitud instando la restitución o el retorno del menor, salvo que existan circunstancias excepcionales que lo hagan imposible (art. 778 quater.5 LEC). Además, la calificación como preferente de este proceso civil especial debe tener como consecuencia concreta que otros procesos sobre guarda y custodia no podrán ser resueltos hasta tanto no se decida primero sobre el proceso de sustracción internacional y sólo cabrá pronunciarse sobre la guarda y custodia cuando en el proceso de sustracción internacional se haya acordado la improcedencia de la restitución

$2^{a}$ En ningún caso se ordenará la suspensión de las actuaciones civiles por la existencia de prejudicialidad penal que venga motivada por el ejercicio de acciones penales en materia de sustracción de menores (art. 778 quater.6 LEC), de tal forma que el principio de celeridad se aplique en su máxima extensión posible en los procesos relativos a la sustracción internacional de menores.

$3^{\text {a }}$ En este tipo de procesos y con la finalidad de facilitar las comunicaciones judiciales directas entre órganos jurisdiccionales de distintos países, si ello fuera posible y el Juez lo considerase necesario, podrá recurrirse al auxilio de las Autoridades Centrales implicadas, de las Redes de Cooperación Judicial Internacional existentes, de los miembros de la Red Internacional de Jueces de la Conferencia de La Haya y de los Jueces de enlace (art. 778 quater.7 LEC).

$4^{a}$ El Juez podrá acordar a lo largo de todo el proceso, de oficio, a petición de quien promueva el procedimiento o del Ministerio Fiscal, las medidas cautelares oportunas y de aseguramiento del menor que estime pertinentes conforme al artículo 773 LEC, además de las previstas en el art. I5 8 CC. Del mismo modo podrá acordar que durante la tramitación del proceso se garanticen los derechos de estancia o visita, relación y comunicación del menor con el demandante, incluso de forma supervisada, si ello fuera conveniente a los intereses del menor (art. 778 quater.8 LEC). En igual sentido, el art. 778 quinquies.5 LEC prevé la posibilidad de adoptar medidas cautelares cuando el demandado no comparece al primer llamamiento o no lo hace en forma, i.e. presentando al menor, por cuando dicho comportamiento procesal del demandado pone de manifiesto un incremento del periculum in mora que hace especialmente aconsejable la adopción, si no se hubiera hecho ya, de medidas cautelares. A fortiori, la Guía de Buenas Prácticas del Convenio de La Haya sobre los aspectos civiles de la sustracción internacional de menores dispone expresamente que «las medidas cautelares pueden jugar un papel muy importante en el éxito y en la rapidez 
con que avance un caso de retorno de La Haya. En algunos casos, puede ser necesario que los Tribunales protejan el bienestar del menor antes de una decisión definitiva. En otros casos, puede ser necesario que los Tribunales prevengan la huida de uno de los padres y del hijo fuera de la jurisdicción o que se le esconda en el interior de la jurisdicción. A tal efecto, la ley de aplicación puede contemplar la posibilidad que el Juez pueda dar una orden previniendo el desplazamiento del menor para evitar una solicitud de retorno, o ordenar la colocación de un menor en situación de custodia temporal a modo de protección si existe riesgo de que el menor sea desplazado fuera de la jurisdicción o escondido en ésta antes de una orden de un Tribunal».

Pues bien, las medidas provisionales que cabe adoptar en estos procesos especiales, con la finalidad de proteger al menor frente a los daños que puedan derivarse de un traslado ilegal, con la salvaguarda de su derecho a relacionarse con ambos progenitores, y con la defensa también de los progenitores a relacionarse con sus hijos, son las previstas en el art. I5 $8 \mathrm{CC}^{30}$; medidas cautelares que cabe solicitar siempre que se acredite que concurre el fumus boni iuris y el periculum in mora. Es evidente, además, que el hecho de que el país al que puede ser trasladado el menor sea o no un Estado de la Unión Europea (de tal forma que le sea de aplicación o no el Reglamento Bruselas II bis) ${ }^{3 \mathrm{I}}$, o haya ratificado o no el Convenio de La Haya sobre los aspectos civiles de la sustracción internacional de menores ${ }^{32}$, debe ser tenido especialmente en cuenta a fin de descartar o, en su caso, modular adecuadamente el periculum in mora para que el Juez determine la adopción de las medidas cautelares correspondientes.

\section{IV.2. Solicitud de incoación del proceso}

El procedimiento se iniciará mediante demanda en la que se instará la restitución del menor o su retorno al lugar de procedencia e incluirá toda la información exigida por la normativa internacional aplicable y, en todo caso, la relativa a la identidad del demandante, del menor y de la persona que se considere que ha sustraído o retenido al menor, así como los motivos en que se basa para reclamar su restitución o retorno Deberá igualmente

\footnotetext{
${ }^{30}$ Recuérdese que las medidas cautelares del art. I58 CC que el Juez puede dictar de oficio o a instancia de parte son las siguientes: I. ${ }^{\circ}$ Las medidas convenientes para asegurar la prestación de alimentos y proveer a las futuras necesidades del hijo, en caso de incumplimiento de este deber, por sus padres. $2 .^{\circ}$ Las disposiciones apropiadas a fin de evitar a los hijos perturbaciones dañosas en los casos de cambio de titular de la potestad de guarda. $3 .^{\circ}$ Las medidas necesarias para evitar la sustracción de los hijos menores por alguno de los progenitores o por terceras personas y, en particular, las siguientes: a) Prohibición de salida del territorio nacional, salvo autorización judicial previa; b) Prohibición de expedición del pasaporte al menor o retirada del mismo si ya se hubiere expedido; c) Sometimiento a autorización judicial previa de cualquier cambio de domicilio del menor. $4 .^{\circ}$ La medida de prohibición a los progenitores, tutores, a otros parientes o a terceras personas de aproximarse al menor y acercarse a su domicilio o centro educativo y a otros lugares que frecuente, con respeto al principio de proporcionalidad. $55^{\circ}$ La medida de prohibición de comunicación con el menor, que impedirá a los progenitores, tutores, a otros parientes o a terceras personas establecer contacto escrito, verbal o visual por cualquier medio de comunicación o medio informático o telemático, con respeto al principio de proporcionalidad. $6 .^{\circ}$ En general, las demás disposiciones que considere oportunas, a fin de apartar al menor de un peligro o de evitarle perjuicios en su entorno familiar o frente a terceras personas. Se garantizará por el Juez que el menor pueda ser oído en condiciones idóneas para la salvaguarda de sus intereses. En caso de posible desamparo del menor, el Juzgado comunicará las medidas a la Entidad Pública.

${ }^{31}$ En este sentido se ha pronunciado, por ejemplo, la SAP Murcia de 20 de febrero de 2014.

${ }^{32}$ Cfr., por todas, ATSJ Cataluña de I9 de junio de 2014 (RJ 20I4\3736); SSAP Barcelona de 9 de mayo de 2014 (JUR 20I4\I78I5I9); de Asturias de 28 de octubre de 20I3 (JUR 20I3/346856); de Barcelona de I8 de julio de 2013 (AC 20I3\I750); de Madrid de 6 de marzo de 2012 (JUR 2OI2\II74O6); de Islas Baleares de 2 de marzo de 2OII (JUR 2OII\I69596).
} 
aportar toda la información que disponga relativa a la localización del menor y a la identidad de la persona con la que se supone se encuentra (art. 778 quinquies.I LEC). Así pues, el petitum del demandante puede ser doble: bien la restitución del menor o bien su retorno ${ }^{33}$.

Además, a la demanda deberá acompañarse la documentación requerida, en su caso, por el correspondiente convenio o norma internacional y cualquier otra en la que el solicitante funde su petición (art. 778 quinquies.r LEC).

Cabe señalar que en atención al principio de celeridad que informa este proceso, y el superior interés del menor que con él se busca proteger, debe realizarse una interpretación flexible de los requisitos formales exigibles, de tal forma que la documentación a presentar habrá de ser la estrictamente imprescindible, evitándose así formalismos superfluos o innecesarios. En todo caso, la no inclusión junto a la solicitud de alguno de los documentos exigidos por el marco convencional internacional que resulte de aplicación no deberá llevar a la inadmisión a radice de la pretensión procesal, sino a la concesión de un plazo de subsanación, conforme al principio pro actione y teniendo en cuenta los delicados intereses subyacentes.

El Letrado de la Administración de Justicia resolverá sobre la admisión de la demanda en el plazo de las 24 horas siguientes y, si entendiera que ésta no resulta admisible, dará cuenta al Juez para que resuelva lo que proceda dentro de dicho plazo (art. 778 quinquies.2 LEC).

En la misma resolución en la que sea admitida la demanda, el Letrado de la Administración de Justicia requerirá a la persona a quien se impute la sustracción o retención ilícita del menor para que, en la fecha que se determine, que no podrá exceder de los tres días siguientes, comparezca con el menor y manifieste si accede a su restitución o retorno, o se opone a ella, alegando en tal caso alguna de las causas establecidas en el correspondiente convenio o norma internacional aplicable (art. 778 quinquies.2 LEC).

El requerimiento se practicará con los apercibimientos legales y con entrega al requerido del texto del correspondiente convenio o norma internacional aplicable (art. 778 quinquies.2 LEC).

Ahora bien, cuando el menor no fuera hallado en el lugar indicado en la demanda, y si, tras la realización de las correspondientes averiguaciones por el Letrado de la Administración de Justicia sobre su domicilio o residencia, éstas son infructuosas, se archivará provisionalmente el procedimiento hasta ser encontrado (art. 778 quinquies.3 LEC).

Por el contrario, si el menor fuera hallado en otra provincia, el Letrado de la Administración de Justicia, previa audiencia del Ministerio Fiscal y de las partes personadas por el plazo de un día, dará cuenta al Juez para que resuelva al día siguiente lo que proceda

\footnotetext{
${ }^{33}$ Aunque la norma no especifica, habrá de entenderse que el «retorno» consistirá en el traslado del menor al lugar de su residencia, mientras que la «restitución» será la entrega del menor a la persona que la ha reclamado, sea ésta realizada en el Estado donde el menor se encuentra sustraído, en el de su residencia habitual o, incluso, en un tercer Estado. Si la sentencia de este proceso de sustracción internacional de menores es estimatoria de la pretensión de restitución del menor a una persona, el mandato judicial se cumplirá con la entrega del menor a esa concreta persona, que será la responsable de desplazarlo ulteriormente a su Estado de residencia. Si la sentencia del proceso de sustracción internacional de menores es estimatoria de la pretensión de retorno del menor, entonces el mandato judicial se cumplirá con el desplazamiento del menor al Estado requirente.
} 
mediante auto, remitiendo, en $\mathrm{su}$ caso, las actuaciones al Tribunal que considere territorialmente competente y emplazando a las partes para que comparezcan ante el mismo dentro del plazo de los tres días siguientes (art. 778 quinquies.3 LEC).

\section{IV.3. Comparecencia}

Llegado el día señalado para la comparecencia por el Letrado de la Administración de Justicia, si el requerido compareciere y accediere a la restitución del menor, o a su retorno al lugar de procedencia, según corresponda, el Letrado de la Administración de Justicia levantará acta y el Juez dictará auto el mismo día acordando la conclusión del proceso y la restitución o el retorno del menor, pronunciándose en cuanto a los gastos, incluidos los de viaje, y las costas del proceso (art. 778 quinquies.4 LEC).

El demandado podrá comparecer en cualquier momento, antes de la finalización del procedimiento, y acceder a la entrega del menor, o a su retorno al lugar de procedencia, siendo de aplicación lo dispuesto en este apartado (art. 778 quinquies.4 LEC).

Por el contrario, si no compareciese, o si comparecido no lo hiciera en forma, ni presentara oposición ni procediera, en este caso, a la entrega o retorno del menor, el Letrado de la Administración de Justicia le declarará en rebeldía en el mismo día y dispondrá la continuación del procedimiento sin el mismo, citando únicamente al demandante y al Ministerio Fiscal a una vista ante el Juez que tendrá lugar en un plazo no superior a los cinco días siguientes. Dicha resolución deberá ser notificada al demandado, tras lo cual no se llevará a cabo ninguna otra, excepto la de la resolución que ponga fin al proceso (art. 778 quinquies.5 LEC).

Como ya se ha apuntado supra subepígrafe 4.I, en caso de que el demandado no comparezca al primer llamamiento o no lo haga debidamente (i.e. presentando al menor), el Juez podrá decretar las medidas cautelares que estime pertinentes en relación con el menor, caso de no haberse adoptado ya con anterioridad, conforme al artículo 773 LEC (art. 778 quinquies.5 LEC).

Por otro lado, si en la primera comparecencia el requerido formulase oposición a la restitución o retorno del menor al amparo de las causas establecidas en el correspondiente convenio o norma internacional aplicable, lo que deberá realizar por escrito, el Letrado de la Administración de Justicia en el mismo día dará traslado de la oposición y citará a todos los interesados y al Ministerio Fiscal a una vista que se celebrará dentro del improrrogable plazo de los cinco días siguientes (art. 778 quinquies.6 LEC).

IV.4. Celebración de la vista

La celebración de la vista no se suspenderá por incomparecencia del demandante. Si fuera el demandado que se hubiera opuesto quien no compareciere, el Juez le tendrá por desistido de la oposición y continuará la vista (art. 778 quinquies.7 LEC).

Ahora bien, cabe realizar dos precisiones a este respecto. En primer lugar, y dado el interés público subyacente en este proceso civil especial no cabe el desistimiento de la Autoridad Central española por lo que, de producirse una inasistencia del Abogado del Estado deberá promoverse la suspensión del procedimiento ya por el propio Juez ya a instancia del Ministerio Fiscal. En segundo lugar, no cabe deducir un desistimiento del 
demandante por actitudes pasivas, de tal forma que sólo podrá darse operatividad al desistimiento del demandante mediante una declaración de voluntad documentada ya que nos encontramos ante una cuestión de orden público internacional. Ahora bien, tampoco debe exigirse la comparecencia personal del requirente al acto de la vista pues dicha comparecencia no se prevé en los Convenios internacionales sobre la materia de los que España es parte ni tampoco en nuestra ley interna y, además, su exigencia supondría una complicación injustificada al retorno incompatible con los principios de celeridad e interés superior del menor que informan este proceso ${ }^{34}$.

Durante la celebración de la vista se oirá a las partes que comparezcan para que expongan lo que estimen procedente, en concreto, a la persona que solicitó la restitución o retorno, al Ministerio Fiscal y a la parte demandada, incluso si compareciere en este trámite por vez primera (art. 778 quinquies.7 LEC).

Se practicarán, en su caso, las pruebas útiles y pertinentes que las partes o el Ministerio Fiscal propongan y las que el Juez acuerde de oficio sobre los hechos que sean relevantes para la decisión sobre la ilicitud o no del traslado o retención y las medidas a adoptar, dentro del plazo improrrogable de seis días. El Juez podrá también recabar, de oficio, a instancia de parte o del Ministerio Fiscal, los informes que estime pertinentes cuya realización será urgente y preferente a cualquier otro proceso (art. 778 quinquies.7 LEC).

En materia probatoria debe puntualizarse que sólo son admisibles pruebas para decidir sobre la ilicitud o no del traslado o retención, sobre la concurrencia de presupuestos fácticos de las excepciones y sobre las medidas a adoptar; siendo especialmente interesante en estos procesos la prueba del derecho extranjero del lugar de residencia habitual del menor, para calibrar si ha existido traslado ilegal, siempre desde la flexibilización de la prueba del derecho extranjero ${ }^{35}$. En sentido inverso, habrán de ser rechazadas las pruebas que traten de articularse para decidir sobre quien tiene mejor derecho para ser custodio del menor.

\footnotetext{
${ }^{34}$ En este sentido se pronuncia, igualmente, la Guía de Buenas Prácticas del Convenio de La Haya sobre los aspectos civiles de la sustracción internacional de menores al disponer que «debido al carácter internacional del Convenio y a las distancias geográficas que se dan, la exigencia jurídica en algunos países de la comparecencia personal del solicitante en el procedimiento en el Estado requerido puede ocasionar retraso en los procedimientos y añadir unos gastos excesivos para el solicitante. Requerir la presencia personal del demandante en los procedimientos, puede provocar, en algunos casos, la imposibilidad de recurrir al Convenio».

${ }^{35}$ En este sentido, resulta clarificadora PÉREZ Vera E., Informe explicativo del Convenio núm. XVIII de la conferencia de La Haya sobre los aspectos civiles de la sustracción de menores, cit., págs. 27 y 29: «La obligación impuesta a las Autoridades centrales de facilitar información sobre el contenido del derecho de su Estado para la aplicación del Convenio aparece en la letra e. Tal deber se refiere especialmente a dos aspectos: por una parte, en el caso de que el traslado haya tenido lugar antes de que se haya dictado una resolución relativa a la custodia del menor, la Autoridad central del Estado de la residencia habitual de este menor podrá expedir una certificación sobre el contenido del derecho de dicho Estado, con vistas a la aplicación del Convenio; por otra parte, la Autoridad central deberá informar a los particulares respecto al funcionamiento del Convenio y de las Autoridades centrales, así como sobre los posibles procedimientos a seguir. En cambio, la posibilidad de ir más allá, es decir de obligar a las Autoridades centrales a asesorar jurídicamente en casos concretos, no se contempla en la norma (...) La prueba del contenido del derecho del Estado de la residencia habitual del menor se puede establecer bien con una certificación, bien con una declaración responsable, es decir mediante documentos que incluyan declaraciones solemnes que comprometan la responsabilidad de sus autores. En cuanto a saber quién puede realizar tales declaraciones, el Convenio ha elegido una fórmula amplia que debe facilitar la tarea del demandante (letra f). Así pues, además de las Autoridades centrales y de las demás autoridades competentes del Estado de la residencia habitual del menor, las declaraciones en cuestión pueden proceder de cualquier persona cualificada, por ejemplo de un Notario, de un abogado o de instituciones científicas».
} 


\section{IV.5. Audiencia del menor}

Antes de adoptar cualquier decisión relativa a la procedencia o improcedencia de la restitución del menor o su retorno al lugar de procedencia, el Juez, en cualquier momento del proceso y en presencia del Ministerio Fiscal, oirá separadamente al menor, a menos que la audiencia del mismo no se considere conveniente atendiendo a la edad o grado de madurez del mismo, lo que se hará constar en resolución motivada (art. 778 quinquies. 8 LEC). De esta forma, podrá omitirse la audiencia del menor tanto cuando se estime que no tiene suficiente juicio para ello como cuanto el propio menor, voluntariamente, deje de comparecer, si se considera que tiene suficiente madurez.

En la exploración del menor se garantizará que el mismo pueda ser oído en condiciones idóneas para la salvaguarda de sus intereses, sin interferencias de otras personas, y recabando excepcionalmente el auxilio de especialistas cuando ello fuera necesario. Esta actuación podrá realizarse a través de videoconferencia u otro sistema similar (art. 778 ter. 8 LEC).

\section{IV.6. Resolución}

Celebrada la vista y, en su caso, practicadas las pruebas pertinentes, dentro de los tres días siguientes a su finalización, el Juez dictará sentencia en la que se pronunciará únicamente sobre si el traslado o la retención son ilícitos y acordará si procede o no la restitución del menor a la persona, institución u organismo que tenga atribuida la guarda y custodia o su retorno al lugar de procedencia para permitir al solicitante el ejercicio del régimen de estancia, comunicación o relación con el menor, teniendo en cuenta el interés superior de éste y los términos del correspondiente convenio o de las disposiciones de la Unión Europea en la materia, según el caso. La resolución que acuerde la restitución del menor o su retorno establecerá detalladamente la forma y el plazo de ejecución, pudiendo adoptar las medidas necesarias para evitar un nuevo traslado o retención ilícita del menor tras la notificación de la sentencia (art. 778 quinquies.9 LEC).

\section{IV.7. Costas procesales}

Si se acordare la restitución o retorno del menor, en la resolución se establecerá que la persona que hubiere trasladado o retenido al menor abone las costas procesales, incluidas aquellas en que haya incurrido el solicitante, los gastos de viaje y los que ocasione la restitución o retorno del menor al Estado donde estuviera su residencia habitual con anterioridad a la sustracción. En los demás casos se declararán de oficio las costas del proceso. (Art. 778 quinquies.Io LEC).

\section{IV.8. Recursos}

Contra la resolución que se dicte sólo cabrá recurso de apelación con efectos suspensivos que, en atención al principio de celeridad que informa este proceso especial, tendrá tramitación preferente, debiendo ser resuelto en el improrrogable plazo de veinte días (art. 778 quinquies.II LEC); plazo procesal que, como afecta a una causa en la que el interés del menor resulta directamente afectado, ha de ser escrupulosamente respectado. Este recurso de apelación produce los efectos devolutivo y suspensivo. Además, tras las 
modificaciones introducidas por la Ley de Jurisdicción Voluntaria en el art. 525 LEC, las sentencias dictadas en los procesos relativos a la restitución o retorno de menores en los supuestos de sustracción internacional no serán en ningún caso susceptibles de ejecución provisional.

A mayor abundamiento, conforme prevé el art. 778 quinquies.II LEC, en la tramitación del recurso de apelación se seguirán las siguientes especialidades:

a) Se interpondrá en el plazo de tres días contados desde el día siguiente a la notificación de la resolución, debiendo el órgano judicial acordar su admisión o no dentro de las 24 horas siguientes a la presentación. Ahora bien, debe tenerse en cuenta que en atención a la naturaleza de la pretensión que se sustancia, los requisitos formales del recurso de apelación deben verse atemperados ${ }^{36}$.

b) Admitido el recurso, las demás partes tendrán tres días para presentar escrito de oposición al recurso o, en su caso, de impugnación. En este último supuesto, igualmente el apelante principal dispondrá del plazo de tres días para manifestar lo que tenga por conveniente.

c) Tras ello, el Letrado de la Administración de Justicia ordenará la remisión de los autos en el mismo día al Tribunal competente para resolver la apelación, ante el cual deberán comparecer las partes en el plazo de 24 horas.

d) Recibidos los autos, el Tribunal acordará lo que proceda sobre su admisión en el plazo de 24 horas. Si hubiere de practicarse prueba o si se acordase la celebración de vista, el Letrado de la Administración de Justicia señalará día para dentro de los tres días siguientes.

e) La resolución deberá ser dictada dentro de los tres días siguientes a la terminación de la vista o, en defecto de ésta, a contar desde el día siguiente a aquel en que se hubieran recibido los autos en el Tribunal competente para la apelación.

IV.9. Ejecución de la sentencia

En la ejecución de la sentencia en la que se acuerde la restitución del menor o su retorno al Estado de procedencia, la Autoridad Central prestará la necesaria asistencia al Juzgado para garantizar que se realice sin peligro, adoptando en cada caso las medidas administrativas precisas (art. 778 quinquies.I3 LEC).

Si el progenitor que hubiera sido condenado a la restitución del menor o a su retorno se opusiere, impidiera u obstaculizara su cumplimiento, el Juez deberá adoptar las medidas necesarias para la ejecución de la sentencia de forma inmediata, pudiendo ayudarse de la asistencia de los servicios sociales y de las Fuerzas y Cuerpos de Seguridad (art. 778 quinquies.I3 LEC).

\section{IV.Io. Sometimiento de la controversia a mediación}

El apartado I3 del art. 778 quinquies LEC regula la posibilidad de recurrir a la mediación intrajudicial también en los procesos relativos a la restitución de menores en

\footnotetext{
${ }^{36}$ En este sentido se pronunció, por ejemplo, la SAP Asturias de I5 de enero de 2008 (AC 2008\I697) FJ $7^{\circ}$.
} 
supuestos de sustracción internacional ${ }^{37}$, siempre y cuando este recurso a la mediación no suponga un retraso injustificado del proceso ${ }^{38}$.

Así, en cualquier momento del proceso ambas partes podrán solicitar la suspensión del mismo de conformidad con lo previsto en el artículo I9.4 LEC, para someterse a mediación. También el Juez podrá en cualquier momento, de oficio o a petición de cualquiera de las partes, proponer una solución de mediación si, atendiendo a las circunstancias concurrentes, estima posible que lleguen a un acuerdo, sin que ello deba suponer un retraso injustificado del proceso. En tales casos, el Letrado de la Administración de Justicia acordará la suspensión por el tiempo necesario para tramitar la mediación. La Entidad Pública que tenga las funciones de protección del menor puede intervenir como mediadora si así se solicitase de oficio, por las partes o por el Ministerio Fiscal (art. 778 quinquies.I2 LEC).

La duración del procedimiento de mediación será lo más breve posible y sus actuaciones se concentrarán en el mínimo número de sesiones, sin que en ningún caso pueda la suspensión del proceso para mediación exceder del plazo legalmente previsto en este capítulo (art. 778 quinquies.I2 LEC).

El procedimiento judicial se reanudará si lo solicita cualquiera de las partes o, en caso de alcanzarse un acuerdo en la mediación, que deberá ser aprobado por el Juez teniendo en cuenta la normativa vigente y el interés superior del niño (art. 778 quinquies.i2 LEC).

Ahora bien, el recurso a la mediación intrajudicial en esta materia también deberá hacerse por los cauces y con las formalidades establecidas en la Ley 5/20I2, de 6 de julio, de mediación en asuntos civiles y mercantiles ${ }^{39}$.

\section{Procedimiento para declaración de ilicitud de un traslado o retención internacional}

El art. I5 del Convenio de La Haya sobre los aspectos civiles de la sustracción internacional de menores prevé que las autoridades judiciales o administrativas de un Estado contratante, antes de expedir una orden para la restitución del menor puedan exigir

\footnotetext{
${ }^{37}$ La previsión de un procedimiento de mediación respetuoso con el derecho a la tutela judicial efectiva es expresamente recogida por el art. 7 de la del Convenio de La Haya sobe los aspectos civiles de la sustracción internacional de menores, que impone a las Autoridades centrales la obligación de facilitar una solución amigable al conflicto, poniendo los medios necesarios para ellos, entro los que se encuentra la mediación familiar.

${ }^{38}$ En este sentido, la Prof. ${ }^{a}$ PÉREZ VERA resulta tremendamente clarificadora en su Informe explicativo del Convenio núm. XVIII de la conferencia de La Haya sobre los aspectos civiles de la sustracción de menores, cit., pág. 27: «La letra c consagra el deber de las Autoridades centrales de tratar de encontrar una solución extrajudicial al asunto. En efecto, según la experiencia expuesta por ciertos delegados, el número de casos que es posible resolver sin tener que recurrir a los tribunales es considerable. Ahora bien, una vez más, es la Autoridad central la que, en esas etapas previas a un eventual procedimiento judicial o administrativo, dirige la evolución del problema; así pues, a ella le corresponde decidir en qué momento han fracasado los intentos llevados a cabo para garantizar la 'restitución voluntaria' del menor, o para facilitar una 'solución amigable’».

${ }^{39}$ Vid., por todos, Barona Vilar, S., Mediación en asuntos civiles y mercantiles en España, Tirant lo Blanch, Valencia, 20I3, passim. También resulta tremendamente ilustrativa la lectura de la Parte V de la Guía de Buenas Prácticas del Convenio de La Haya sobre los aspectos civiles de la sustracción internacional de menores relativa Mediación relativa a la mediación elaborada en 2012 por la Hague Conference on Private Internacional Law que se puede descargar en el siguiente enlace: http://www.hcch.net/upload/guide28mediation_es.pdf
} 
que el demandante obtenga de las autoridades del Estado de residencia habitual del menor una decisión o una certificación que acrediten que el traslado o retención del menor es ilícito conforme a la definición de dicho Convenio internacional, siempre que pueda obtenerse en dicho Estado esa decisión o certificación.

Pues bien, otra de las novedades introducidas por la Ley de Jurisdicción Voluntaria en la Ley de Enjuiciamiento Civil es el art. 778 sexies, que incorpora un procedimiento para obtener una resolución que especifique que el traslado o la retención han sido ilícitos; procedimiento referido a supuestos en los que un menor con residencia habitual en España sea objeto de un traslado o retención internacional

Así, Cuando un menor con residencia habitual en España sea objeto de un traslado o retención internacional, conforme a lo establecido en el correspondiente convenio o norma internacional aplicable (y singularmente el art. I5 del Convenio de La Haya antedicho), cualquier persona interesada, al margen del proceso que se inicie para pedir su restitución internacional, podrá dirigirse en España a la autoridad judicial competente para conocer del fondo del asunto con la finalidad de obtener una resolución que especifique que el traslado o la retención lo han sido ilícitos, a cuyo efecto podrán utilizarse los cauces procesales disponibles en el Título I del Libro IV de la Ley de Enjuiciamiento Civil para la adopción de medidas definitivas o provisionales en España, e incluso las medidas del artículo I58 CC (art. 778 sexies LEC).

La autoridad competente en España, para emitir una decisión o una certificación del art. I5 del Convenio de La Haya de 25 de octubre de I980 sobre los aspectos civiles de la sustracción internacional de menores, que acredite que el traslado o retención del menor es ilícito en el sentido previsto en el artículo 3 del Convenio de La Haya de i980, cuando ello sea posible, lo será la última autoridad judicial que haya conocido en España de cualquier proceso sobre responsabilidad parental afectante al menor. En defecto de ello, será competente el Juzgado de Primera Instancia del último domicilio del menor en España. La Autoridad Central española hará todo lo posible por prestar asistencia al solicitante para que obtenga una decisión o certificación de esa clase (art. 778 sexies LEC).

Debemos concretar, por lo tanto, qué debe considerarse traslado o retención ilícitos del menor a los efectos de su acreditación mediante este nuevo procedimiento. Para ello cabe comenzar citando la muy esclarecedora STS de 26 de octubre de 2012 (RJ 20I2\9730), en cuyo FJ $2^{\circ}$ se dispone: «la guarda y custodia de los menores deriva de la patria potestad y de la patria potestad, entre otras cosas, deriva la fijación del domicilio familiar, según dispone el artículo 70 del Código Civil, para dar cumplimiento a lo previsto en el artículo 68 del Código Civil , respecto de la obligación de vivir juntos (...) Estamos, sin duda, ante una de las decisiones más importantes que pueden adoptarse en la vida del menor y de la propia familia, que deberá tener sustento en el acuerdo de los progenitores o en la decisión de uno de ellos consentida expresa o tácitamente por el otro, y solo en defecto de este acuerdo corresponde al juez resolver lo que proceda previa identificación de los bienes y derechos en conflicto a fin de poder calibrar de una forma ponderada la necesidad y proporcionalidad de la medida adoptada, sin condicionarla al propio conflicto que motiva la ruptura». De esta forma, cuando se dicta una resolución jurisdiccional estándar (singularmente en un proceso de separación, nulidad o divorcio) en la que, atribuyéndose la patria potestad conjunta y la guardia y custodia a uno de los progenitores, no se hace ningún pronunciamiento en cuanto a la facultad de decidir la residencia del menor, esta 
facultad corresponde a ambos progenitores de común acuerdo y, en su defecto a la decisión judicial $^{40}$. En fin, desde la perspectiva del Derecho interno español, un traslado con cambio de residencia de un menor por uno de los progenitores a un tercer país sin el consentimiento expreso o tácito del otro progenitor, cuando ambos son cotitulares de la patria potestad, es un traslado ilícito a los efectos del art. 3 del Convenio de La Haya sobre los aspectos civiles de la sustracción internacional de menores, aún en el caso de que la guardia y custodia esté atribuida exclusivamente al progenitor que lleva a cabo el mencionado traslado.

Por lo tanto, si un progenitor que comparte la patria potestad con el otro quiere modificar la residencia del menor y establecerla en un tercer país debe pedir al otro progenitor que preste su consentimiento. Si el otro progenitor no lo presta, deberá acudir al Juez para que en su caso autorice el cambio de residencia, siguiendo para ello el procedimiento previsto en el art. 778 sexies LEC.

En efecto, la STS de 20 de octubre de 2014 (RJ 20I4\5376) ha declarado como doctrina jurisprudencial la siguiente: «el cambio de residencia del extranjero progenitor custodio puede ser judicialmente autorizado únicamente en beneficio e interés de los hijos menores bajo su custodia que se trasladen con él». En este sentido, en el ámbito de la Conferencia de La Haya de Derecho Internacional Privado, la Declaración de Washington sobre la reubicación internacional de familias de 20io sostuvo que «en todas las solicitudes relacionadas con la reubicación internacional la consideración primordial es el beneficio del niño. Por lo tanto, las determinaciones deben tomarse sin ninguna suposición a favor o en contra de la reubicación». Además, «para identificar con mayor claridad los casos en los que se debe conceder o negar la reubicación, y con el objetivo de impulsar un enfoque internacional más uniforme, el ejercicio de la discreción judicial debe estar regido en especial, aunque no únicamente, por los siguientes factores en ningún orden de prioridad. La importancia que se le dará a un factor determinado será diferente de un caso a otro:

i) El derecho del niño separado de uno de sus padres a mantener relaciones personales y contacto directo con ambos progenitores regularmente y de un modo que concuerde con el desarrollo del niño, salvo que el contacto se contraponga con el beneficio del niño;

ii) Las opiniones del niño teniendo en cuenta su edad y madurez;

iii) Las propuestas de las partes con respecto a los arreglos prácticos de la reubicación, que incluyen alojamiento, educación y empleo;

\footnotetext{
${ }^{40}$ Así se ha pronunciado, por ejemplo la SPA Castellón de Io de septiembre de 20 Io (JUR 20II $\backslash 25772$ ) al disponer FJ $2^{\circ}$ : «la atribución de la guarda y custodia sobre un menor no conlleva que el titular de aquella tenga la libérrima facultad de decidir, sin limitaciones, el domicilio del menor sometido a dicha guarda y custodia. Nos parece evidente que el derecho fundamental (art. Iو de la Constitución) del progenitor custodio a elegir su lugar de residencia, no puede desvincularse de los intereses del menor que tan drásticamente pueden verse afectados por un ejercicio irresponsable de dicho derecho fundamental. Tal y como decíamos en nuestra sentencia antes citada, 'Este es también el planteamiento que se sigue en el ATC I27/86, de I2 de febrero de I986 (RTC I986, I27), sobre la existencia de cargas, gravámenes o limitaciones que puedan afectar a la libertad de establecimiento y de fijación del lugar de residencia, en supuestos en los que la limitación viene impuesta por un interés protegido de manera privilegiada en el Ordenamiento jurídico, como es el de los hijos menores' (...). En principio, por tanto, un cambio de domicilio relevante para la vida del menor es una cuestión que debería ser decidida conjuntamente por los dos cotitulares de la patria potestad, y, en defecto de acuerdo, por la autoridad judicial (arts. I56 y I03. I $^{\circ}$ c) del Código Civil)». En el mismo sentido se han pronunciado posteriormente las SSAP Castellón de 28 de noviembre de 2012 (JUR 20I3186309), FJ $2^{\circ}$, y 6 de septiembre de 2013 (JUR $2013 \backslash 349850)$, FJ $2^{\circ}$.
} 
iv) Cuando sea importante para la determinación del resultado, los motivos a favor y en contra de la reubicación;

v) Cualquier antecedente de violencia o abuso familiar, ya sea físico o psicológico;

vi) Los antecedentes de la familia y en especial la continuidad y calidad de arreglos de contacto y asistencia actuales y anteriores;

vii) Determinaciones de custodia y visitas preexistentes;

viii) El impacto que producirá la concesión o la negación de la reubicación en el niño, en el contexto de su familia extensa, su educación y vida social, así como en las partes;

ix) La naturaleza de la relación entre los padres y el compromiso que asume el solicitante para sustentar y facilitar la relación entre el niño y el demandado después de la reubicación;

x) Si las propuestas de las partes para el contacto posterior a la reubicación son realistas, teniendo alguna consideración especial con respecto al costo para la familia y la carga para el niño;

xi) La aplicabilidad de las disposiciones del contacto que rigen como condición de reubicación en el estado de destino;

xii) Problemas de movilidad para los integrantes de la familia; y

xiii) Cualquier otra circunstancia que el Juez considere relevante» ${ }^{4 \mathrm{~T}}$.

${ }^{4}$ Cfr. la Declaración de Washington sobre la reubicación internacional de las familias en la web http://www.hcch.net/upload/decl_washington2oros.pdf Igualmente interesante resulta la lectura de la Nota preliminar sobre la reubicación familiar internacional, elaborada también por la Conferencia de La Haya de Derecho Internacional Privado en el año 20I2, cuyo texto se puede consultar en la web: http://www.hcch.net/upload/wop/abduct2oı2pdiıs.pdf 